\title{
札幌市における都市化が緑地の植物相に与えた影響
}

\section{Effects of Urbanization on the Flora of Open Space in Sapporo City}

矢部和夫* 吉田恵介* 金子正美**

Kazuo YABE Keisuke YOSHIDA Masami KANEKO

\begin{abstract}
摘要 : 札幌市の 11 緑地の植物相を主成分分析法によって解析した。第 1 軸は孤立化指標（周辺の森 林率，孤立後の時間）之負相関を持ち，森林植物の種数之も負相関を持った。孤立化は市街地拡大の 指標でもあるため, この軸は緑地の都市化によって森林植物が減少することを抽出した。第 2 軸は, 緑地内の䚓乱地の増加により雑草種が増加するという人為的な影響を抽出した。都市化によって消失 する森林植物は 30 種の草本と 14 種の木本であった。また鳥散布型の木本は孤立化によって消失しゃ すく，周辺 $100 \mathrm{~m}$ 以内の森林率が孤立化に影響を与えやすかった。さらに，30種の草本が林床性であ ることから，断片化（小面積化）の影響が大きいものと思われる。
\end{abstract}

\section{1.はじめに}

札幌市の市域面積は，日本の 13 大都市の巾で最も大きいが， 市域の中で市街化区域の占める割合は $21.9 \%$ であり 3 番目に小さ い(大都市統計協議会, 1997) 。しかし都市計画法が施行されて 以来，引き続き市街地の拡大が続いて扔り，1970 年から 1997 年 にかけて市街化調整区域から市街化区域に変更された面積は，約 2,600haであり，10.7\%の増加率を示している（札幌市,1997）。 現在市域の約 6 割が農地・山林・原野等の緑地で占められている が，急速に進展する市街化区域の拡大の山で，これらの緑地は今 後急速に減少するものと予想される。

旧市街地の公園緑地を見ると, 地区公園以上:の公園緑地は周辺 部にいくつかあるものの, 中心部には少ない。また, 新市街地で は, 開発行為によって生み出された公園が多く, 市域全体で見る 之, 公園の数は多い屯のの, 街区公園の平均面積は $872 \mathrm{~m}^{2}$ （札沅 市, 1997) ${ }^{15)}$ と小さい。この大きさは, 区画整理による公園（平均 面積 2,706 m²（札幌市，1997） ${ }^{155}$ ）などと比較するとかなり小さく, 扇状地形で比較的平坦な书街地の緑地の大きさとしては緑被率, 緑視率とも十分とはいえない。一方，市街化調整区域の連続した 緑地の掂がりをみると，一部国有林があるが，多くは民有林であ り, 土砂採掘, 宅地造成等により, 緑地の不連続化が進んでいる。 こういった状況の中で, 現在西部山岳地带之市街地を結ぶ連続し た緑地の保全と再生が急務となっているが, これらをより効果的 に行うための基礎資料がほとんどないのが現状である。この研究 は札幌市の緑地計画のなかで緑地の生物相の保全を適正に行うた めの基礎的研究として, 都市化が緑地の植物相構造によ゙のような 影響を与えているかを解明することを目的としている。

本研究は次の 4 段階からなる。（1）札幌市域の 11 筒所の緑地 の種組成を主成分分析法によって解析する。（2）孤立化の指標, 土地利用区分, 森林斑の形状や面積, 公園利用強度などの外的要 因や, 各緑地の構成種の生育地特性や生育形による各分類種群の 種数を求める。（3）これらの要因と主成分軸上に抽出された種 組成上の構造との相関係数を求め, 緑地の植物相の構造の解明及 び構造に影響を与える要因を明らかにする。（4）さらに都市化 要因に対してどのような種の分布が敏感に反応するかについても 検討する。

\section{2. 調査地の概況と方法}

\section{（1）調査地の概況}

札幌市は北緯 $42^{\circ} 27^{\prime} \sim 43^{\circ} 11^{\prime}$ ，東経 $140^{\circ} 59^{\prime} \sim 141^{\circ} 30$ に位罱する。市の南西部は山地带となって抢り，中央部は豊平川 水系がつくった低地の扇状地形の先端付近にある。また北東部は 豊平川上その本流である石狩川のつくった沖積平野であり, む之 もと泥炭地が拡がっていた。市中心部の月別平均気温は一 $4.6^{\circ} \mathrm{C}$ $\sim 21.7^{\circ} \mathrm{C}$ の範囲にあり，年降水量は $1,129.6 \mathrm{~mm}$ である（1960 体か ら 1990 年までの平均值)。

調查対象緑地は市中心部に分布する11 緑地である(間-1)： 大谷地の森 (以下大谷地), 青葉中央公園十上野幌公園 (青葉), ポプラ通風致地区（ポプラ通），西岡公園 (西岡), 藻南公園 (藻

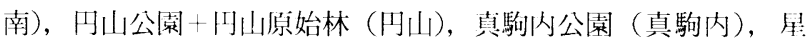
置緑地 (星置), 北海道大学: (北大), JR 東札幌跡地 (東札幌), 野棍森林公園 (野幌)。これらの緑地のうち，西岡内の森林は南

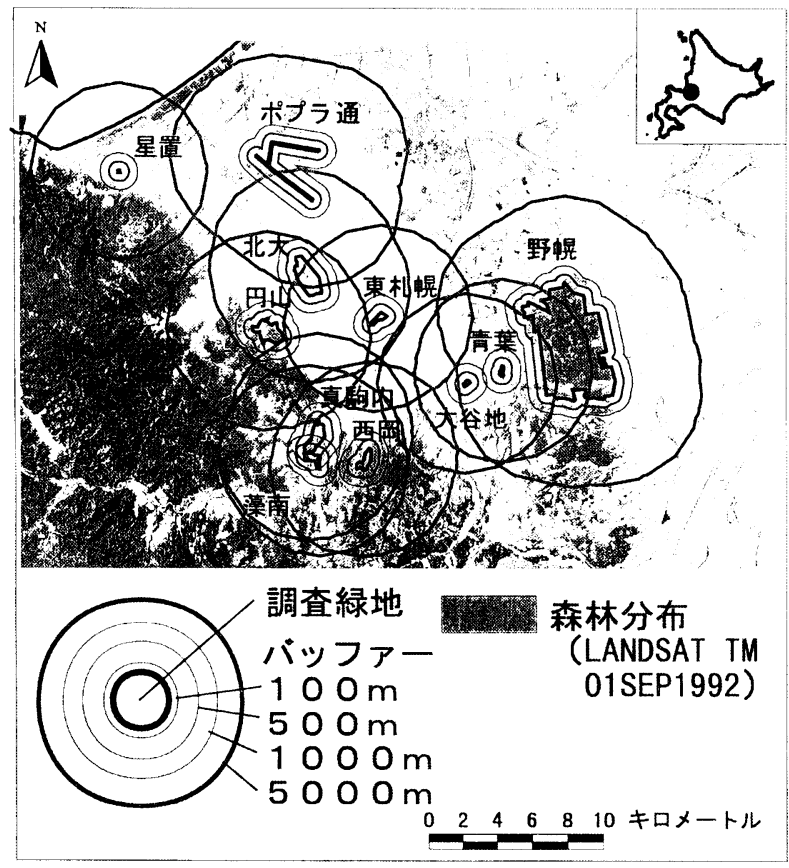

図-1＼cjkstart札幌市中心部の森林の分布と調査緑地の位置

\footnotetext{
“札幌市立高等専門学校インダストリアルデザイン学科環境デザイン “北海道環境科学研究センター自然環境部
} 
部の山地帯の森林地帯と連続しているため孤立化していない。ま た澡南と真駒内は隣接している。野幌は他の緑地に比べきわめて 大きな森林斑を保有している。一方, 東札幌には森林はほとんど ない。

\section{(2) 方法}

(i) 緑地の特性

1/2,500 に拡大した航空写真（1996 年8月 20 日撮影）から各 緑地の面積と緑地内の森林面積と草地・草原・耕地面積をプラニ メーターによってそれぞれ求めた。この際, 緑地内の森林につい ては森林斑が $10 \mathrm{~m}$ 以上のものを測定した。緑地で最大の森林斑 はその面積と周囲長をプラニメーター上キルビメーターで求め, その形状指数 (日置, 1993) 学求めた。多くの緑地では最大森 林斑は対象緑地の区域外にはみ出していた。また西岡は周井の森 林帯と連続していたので, 最大森林斑の測定は不可能であった。 各緑地の利用強度の推定值として, 都市公園管理台帳平面図（札 幌市公園管理課）より, 緑地内の道路や歩道の総延長を園路長と して求め, これらを基に, 園路長比（園路長／緑地面積 $\times 10000$ ） を求めた。

\section{(ii) 孤立化の指標}

各緑地がどの程度孤立化しているかを推定するために，GIS (Arcview3) 上で各緑地の外縁から $100 \mathrm{~m}, 500 \mathrm{~m}, 1,000 \mathrm{~m}, 5,000 \mathrm{~m}$ の周辺ゾーン(バッファー) を発生させ, 各ゾーン内の森林率を 求めた。森林分布は 1992 年 9 月 1 日に撮影されたLANDSAT TM 画像を土地被覆分類し, 森林ピクセルのみを抽出し作成した。 ピクセルサイズは $30 \times 30 \mathrm{~m}$, 使用した画像解析ソフトは ERDAS IMAGENE8.2である。周辺ゾーンを 5,000 mにまで 拡大する之，互いに他の緑地区域のいくつかを包含するように

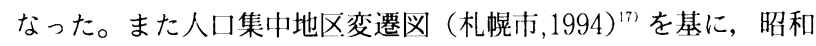
35 年から 5 年每に人口集中地区（4,000人/ $\mathrm{km}^{2}$ 以上地域）となっ た年代を求め,これを孤立化した年代とした。

\section{(iii) 植物相}

各緑地の植物相は「札幌の植物」(原， 1992） ${ }^{5}$ から引用した。 記載されたすべての種はそれぞれ「札幌の植物」中の生育地区分 を参考にして, 次の 8 型の生育地特性種群に分類した：森林種, 海岸種, 岩れき地種, 砂丘・砂浜種, 湿原種, 樹幹種, 沢筋種之 耕地種・人里種。生育形については, 草本種（着生植物之水生植 物を除く), 高木種（樹高が $4 \mathrm{~m}$ 以上になる種）, 低木種（樹高が $4 \mathrm{~m}$ に達しない種), 草本性つる種, 木本性つる種とその他（着 生植物之水生植物）に分類した。またこれらの分類とは別に各緑 地の帰化種数, 単位面積当たりの帰化種数之帰化率（帰化種数 総種数 $\times 100 \%$ ）求めた。

(iv) 植物相データの解析

植物相データは CANOCO ver 3.11 を用い, 種間の分散共分 散行列から主成分分析(Orloci, 1973) ${ }^{13)}$ を行い, 最大の 3 軸を算
出した。11 緑地で総種数 833 種が記載されたが,これから記載 出現回数 11 回, 2 回と 1 回の種を除いたところ，464 種となっ た。

調査緑地は最大で $1,800 \mathrm{ha}$ の大面積のものを含んでおり，こ のような大規模な緑地内には樣々な立地環境に成立した多種類の 植物群落型が存在する。このため緑地間の種数や種組成に対する 都市化の影響を検討する場合は，立地環境の多様さによる影響を 考虑する必要がある。種組成に対する影響については以下のよう な前処理をした。各立地環境に対応する群落型はそれぞれ特有な 種群を含むため, このような種群内の種間には非常に高い分布相 関が発生する。主成分軸が本研究の目的である都市化の影響を抽 出しやすいようにするために, 記載出現パターンが完全に一致す る種群（分布相関 $\mathrm{r}=1.0$ ）功それぞれ 1 種を残して他の種を 除いた。この結果, 種数は 250 種に減少した。緑地の総種数につ いては，これを立地環境に対応する前述の各生育地特性別の種群 （森林種，耕地・人里種等）の種数や帰化種数に分けた。また緑 地の各立地環境区分（森林，草地・草原・農地）ごとにその面積 を求め, 各立地面積とそれに対応する種群の種数の関係を主成分 分析の結果から検討した。

ter Braak \& Prentice (1988) ${ }^{20)}$ は種組成の変化が小さい場合 は主成分分析による線形の序列化の方が非線形の序列化よりも優 れているとしている。さらに加藤 $(1995)^{10)}$ は，この目安として データにおける総種数が各地点の平均種数の 3 倍以下であれば, 主成分分析が適当であるとしている。本研究のデータは総種数 250 種に対し, 各地点の平均種数が 122.7 種であり, 主成分分析 を行う上で十分な均質性を持っていた。なお，種デー夕による反 復平均法と要因デー夕による重回帰分析を結合した非線形の序列 化である Canonical Correspondence Analysis (ter Braak 1986) ${ }^{199}$ は本研究では面積べースの要因が多く, 各範囲で の緑地周辺森林摔相互間や, 緑地面積之緑地内の森林面積間など で自動相関が発生すること及び緑地の種組成データが非常に均質 であることから, 本研究での解析には不向きであった。次に主成 分軸と各要因との相関係数を求め, 重要な要因を抽出した。この 際, 面積デー夕は、変換をし，\%データは $\arcsin$ 変換をした。

\section{3. 結果}

\section{（1）各緑地の特性}

緑地面積は非常にばらつきがあり, 最大の野幌が 2,000ha で あり他よりも著しく大きく, 北大 (180ha), 円山 (130ha) 之真 駒内（84ha）がこれに次いだ(表一1)。小さな緑地は青葉（9 ha), 大谷地 ( $7 \mathrm{ha}$ ) と星置 (1 ha) であった。森林面積は野 幌（1,800ha）が最も広く, 円山(100ha) と真駒内 (46ha) が これに次ぎ, 東札幌 (0.04ha) では森林はほとんど分布しなかっ た。草地・草原・農地面積は野幌 (160ha), 北大 (75ha) と真

表 -1 各緑地の特性

\begin{tabular}{|c|c|c|c|c|c|c|}
\hline & $\begin{array}{l}\text { 森林面積 } \\
\text { (ha) }\end{array}$ & $\begin{array}{l}\text { 草地- 草原 - } \\
\text { 地面積 (ha) }\end{array}$ & 地面積（ha） & $\begin{array}{l}\text { 最大森林斑の } \\
\text { 面積 (ha) }\end{array}$ & 形状指数 & 園路長比 \\
\hline 大谷地 & 4.78 & 0.44 & 7.41 & 2.78 & 1.11 & 51.0 \\
\hline 青葉 & 6.77 & 1.16 & 9.33 & 5.66 & 3.12 & 97.6 \\
\hline ポプラ通 & 13.67 & 0.03 & 13.70 & 4.29 & 2.04 & 13.7 \\
\hline 西岡 & 24.26 & 5.14 & 35.50 & - & - & 42.3 \\
\hline 藻南 & 10.05 & 2.97 & 22.15 & 35.76 & 2.62 & 21.2 \\
\hline 円山 & 105.41 & 6.51 & 129.71 & 66.66 & 2.37 & 27.9 \\
\hline 真駒内 & 46.30 & 26.87 & 83.55 & 35.76 & 2.62 & 73.7 \\
\hline 星置 & 1.03 & 0.00 & 1.03 & 1.03 & 1.21 & 247.9 \\
\hline 北大 & 40.80 & 74.85 & 180.56 & 8.00 & 4.70 & 79.2 \\
\hline 東札楐 & 0.04 & 9.02 & 14.87 & 0.02 & 1.34 & 36.6 \\
\hline 野幌 & 1822.06 & 162.75 & 2019.10 & 765.00 & 5.30 & 22.5 \\
\hline
\end{tabular}


駒内（27ha）で広く, ポプラ通（0.03ha）や星置（0ha）には ほとんど見られなかった。最大森林斑は野幌（770ha）で他の緑 地よりも著しく大きく, ついで円山 (67ha), 藻南 (36ha) と真 駒内（36ha）で大きかった。また，東札幌（0.02ha）では著し く小さかった。最大森林斑の形状指数は野幌, 北大と青葉で高く, 複雑な形をしていたが, 東札幌, 星置と大谷地では低く, 単純な 形をしていた。園路長比は星置で最も大きく, 青葉, 北大と真駒 内がこれに次いで大きかった。一方, 野幌, 藻南とポプラ通では 小さかった。

\section{（2）孤立化指標}

緑地の周辺 $100 \mathrm{~m}$ 地域の森林率は西岡で著しく高く, ついで円 山, 藻南, 野幌と星置で高かった（表一2）。一方, ポプラ通, 北大と東札幌では著しく低かった。周辺 $500 \mathrm{~m}$ 地域の森林率は, 森林摔の非常に低い東札幌を除き, 周辺 $100 \mathrm{~m}$ 地域よりも森林膟 が低下した。ところが $5,000 \mathrm{~m}$ まで周辺距離を拡大すると，西岡， 円山上野幌では周辺 $500 \mathrm{~m}$ 地域よりも森林淬が減少したが，他の 緑地では增加した。このように周辺地域を拡大したときの森林率 の增減パターンの違いは, 市街地における緑地の位置によるとこ ろが大きい(図-1)。市街地中心部に位置する緑地は, 周辺地 域の範同を狭くとる場合は森林摔が少ないが，周辺地域の範用を 拡大していくと森林率は市街地縁部の森林地带を含むために増加 する。逆に市街地の周辺部に位置する緑地は, 周辺地域の範囲を 拡大すると, より多くの市街地を含むようになるために, 森林率 が低下する。孤立してからの年数は北大, 東札幌と青葉で多く, 円山，星置と大谷地では少なかった。また西岡は現在も孤立化し ていない。

（3）各緑地の総種数, および生育形別種数と生育形スペクトル 各緑地の総種数は野幌, 西岡, 円山上真駒内で多く, 東札幌で は特に少なかった（表一 3 )。一方，単位面積あたりの種数は， 星置だけが著しく大きく, 次いで大谷地が多かった（表一 4)。 総種数が最大であった野幌は，単位面積あたりではその種数が最 低になった。緑地間での総種数の違いは，その大半を占める草本
表一 2 緑地周辺の森林率 $(\%)$ と孤立してからの時間

\begin{tabular}{|c|c|c|c|c|c|}
\hline & \multicolumn{4}{|c|}{ 緑地周辺の森林棝 } & \multirow{2}{*}{$\begin{array}{l}\text { 坬立化して } \\
\text { からの時間 }\end{array}$} \\
\hline & 周辺 $100 \mathrm{~m}$ & 周辺 $500 \mathrm{~m}$ & 周辺 $1000 \mathrm{~m}$ & 周辺 $5000 \mathrm{~m}$ & \\
\hline 大谷地 & 29.3 & 20.2 & 15.4 & 26.1 & 27 \\
\hline 青莗 & 34.1 & 20.3 & 18.6 & 38.1 & 52 \\
\hline ポプラ通 & 20.9 & 17.9 & 16.1 & 19.0 & 47 \\
\hline 西网 & 84.9 & 81.1 & 80.9 & 55.5 & 0 \\
\hline 藻南 & 47.9 & 40.4 & 45.1 & 61.9 & 42 \\
\hline 円山 & 50.1 & 44.2 & 42.5 & 42.8 & 32 \\
\hline 真駒内 & 41.2 & 32.7 & 37.3 & 55.9 & 42 \\
\hline 星置 & 45.8 & 34.3 & 34.8 & 45.2 & 32 \\
\hline 北大 & 18.6 & 13.0 & 8.7 & 16.4 & 57 \\
\hline 東札谠 & 3.1 & 4.4 & 5.2 & 12.6 & 57 \\
\hline 野幌 & 46.4 & 38.4 & 37.5 & 34.4 & 47 \\
\hline
\end{tabular}

種と高木種の種数の違いによってもたらされたものであった。構 成種の草本種之高木種の種数は野幌之西岡で多かったが，東札幌 で最低であった（表一-3）。生育形スペクトルでみると（表-4）, 草本種の割合は東札幌で著しく高く，青葉で最低であった。また, 高木種の割合は，青葉や大谷地で高かった。

低木種は真駒内, 西岡, 野坭之藻南で多く, 星置と北大で少な く, 東札幌にはなかった。草本性つる種は野幌, 西岡之藻南で多 く, 青葉, 大谷地と東札幌で少なかった。一方，木本性つる種は 西風，冈山，真駒内之野幌で多く,東札幌にはほとんどなかった。 これらの種群の生育形スペクトルは, 種数で得られた傾向と類似 していた。

\section{（4）生育地特性別種数}

生育地特性別種数をみる之（表一 5 ), 森林種が著しく多く, 耕地・人里種がこれに次いで多かった。従ってこれらの 2 つ種 群が, 各緑地の総種数に対して大きく寄与していることがわかっ た。森林種の種数は野幌, 西岡, 真駒内之円山で多く, 東札帵に はほとんよ゙なかった。沢筋種と樹幹種（着生種）の種数もほぼ同 様の傾向にあった。

耕地・人里種は北大，ポプラ通，野幌と円山で多く，星置，大 谷地之青葉で少なかった。岩れき地種は藻南, 円山之真駒内で多 かった。帰化種のほとんよ゙は耕地・人里種に含まれるため, 緑地
表 -3 各緑地の総種数と生育形別種数

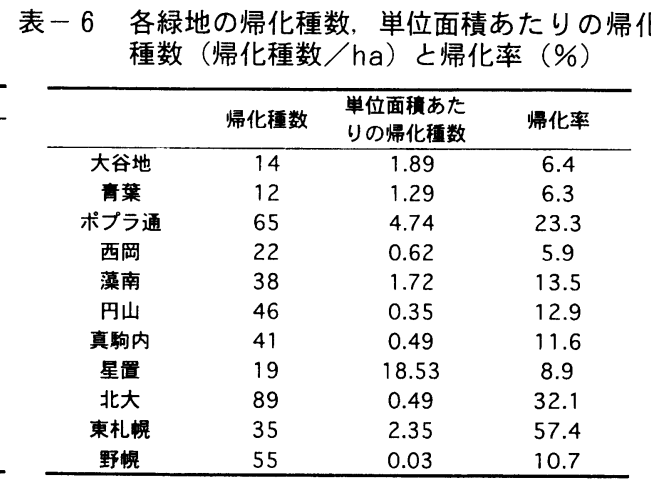

表-4 各緑地の単位面積当たり種数（種数／ha）と各生育形 のスペクトル $(\%)$

\begin{tabular}{|c|c|c|c|c|c|c|c|}
\hline & $\begin{array}{l}\text { 単位面㮴当 } \\
\text { たりの程数 }\end{array}$ & 草本 & 高木 & 低木 & 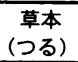 & $\begin{array}{l}\text { 木本 } \\
\text { (つる) }\end{array}$ & その他 \\
\hline 大谷地 & 29.4 & 69.3 & 16.5 & 9.2 & 0.9 & 4.1 & 0.0 \\
\hline 青葉 & 20.5 & 64.4 & 18.8 & 11.0 & 2.1 & 3.7 & 0.0 \\
\hline ポプラ通 & 20.4 & 74.6 & 9.7 & 7.9 & 4.7 & 2.5 & 0.7 \\
\hline 西岡 & 12.0 & 72.8 & 12.4 & 7.0 & 3.8 & 3.1 & 0.9 \\
\hline 藻南 & 12.7 & 67.0 & 14.2 & 9.9 & 5.3 & 3.5 & 0.0 \\
\hline 円山 & 2.8 & 73.9 & 11.8 & 7.0 & 3.4 & 3.4 & 0.6 \\
\hline 真呴内 & 4.2 & 70.9 & 12.1 & 10.2 & 3.1 & 3.4 & 0.3 \\
\hline 星置 & 208.7 & 72.9 & 11.2 & 7.5 & 4.7 & 3.7 & 0.0 \\
\hline 北大 & 1.5 & 76.2 & 10.5 & 2.9 & 4.3 & 3.2 & 2.9 \\
\hline 東札聣 & 4.1 & 96.7 & 0.0 & 0.0 & 1.6 & 1.6 & 0.0 \\
\hline 野晅 & 0.3 & 76.9 & 10.5 & 5.6 & 3.3 & 2.3 & 1.4 \\
\hline
\end{tabular}

\section{表 -5 各緑地の生育地特性別種数}

\begin{tabular}{|c|c|c|c|c|c|c|c|c|}
\hline & 森林 & 沢筋 & 撽幹 & $\begin{array}{l}\text { 耕地·人 } \\
\text { 里. }\end{array}$ & $\begin{array}{l}\text { 岩れき } \\
\text { 地 }\end{array}$ & 湿原 & 海摩 & $\begin{array}{c}\text { 砂丘 } \\
\text { 砂浜 }\end{array}$ \\
\hline 大谷地 & 179 & 9 & 0 & 22 & 4 & 3 & 0 & 1 \\
\hline 青葉 & 152 & 11 & 0 & 19 & 4 & 5 & 0 & 0 \\
\hline ポプラ通 & 150 & 12 & 0 & 92 & 0 & 24 & 0 & 1 \\
\hline 西岡 & 341 & 22 & 2 & 33 & 7 & 19 & 1 & 1 \\
\hline 藻南 & 194 & 16 & 0 & 51 & 16 & 4 & 1 & 0 \\
\hline 円山 & 250 & 18 & 2 & 74 & 11 & 1 & 0 & 1 \\
\hline 真䣱内 & 258 & 13 & 1 & 60 & 10 & 9 & 2 & 1 \\
\hline 星置 & 164 & 9 & 0 & 29 & 1 & 10 & 0 & 1 \\
\hline 北大 & 124 & 13 & 2 & 119 & 1 & 17 & 0 & 1 \\
\hline 東札幅 & 9 & 0 & 0 & 50 & 0 & 2 & 0 & 0 \\
\hline 里愢 & 360 & 18 & 5 & 84 & 4 & 41 & 2 & 1 \\
\hline
\end{tabular}




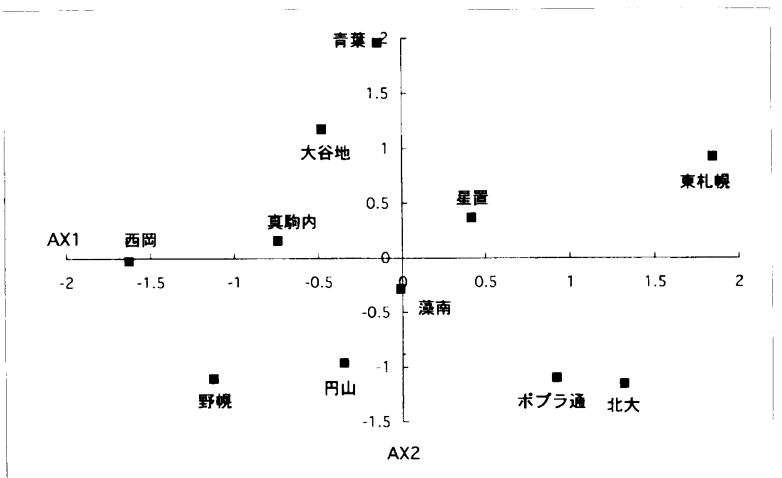

図一 $2 A X 1$ と $A X 2$ 上の各緑地の配置

間での帰化種数の違いは耕地・人里種数の違いと相関が高く, 北 大やポプラ通で多く大谷地や青葉で少なかった（表-6）。一方, 単位面積あたりの帰化種数は星置やポプラ通で多かったが, 円山 や野棍では少なかった（表一6）。帰化率は, 総種数之帰化種数 の大小に影響を受けるため, 帰化種数の多少の傾向と異なり, 東 札幌で最大となった。

湿原種は野幌で特に多く，ポプラ通，西岡と北大でも多かった。 海岸種之砂斤・砂浜種は記載出現種数が非常に少なかった。

（5）主成分分析による緑地の序列化

主成分分析の第 1 軸 AX1 の全分散に対する固有値（ $\lambda$ ） と寄 与率は $\lambda:=118.6$ と $19.5 \%$ であり, 第 2 軸 AX2 と第 3 軸 AX3 はそれぞれ $\lambda_{2}=94.9,15.6 \%$ \% $\lambda_{3}=74.8,12.3 \%$ あった。最 大の AX1は3 軸のなかで最も緑地を分散させ，負側から正側に かけて西岡 $\rightarrow$ 野幌 $\rightarrow$ 真駒内 $\rightarrow$ 大谷地 $\rightarrow$ 円山 $\rightarrow$ 青葉 $\rightarrow$ 藻南 $\rightarrow$ 星置 $\rightarrow$ ポプラ通 $\rightarrow$ 北大 $\rightarrow$ 東札幌の順に緑地を配置した（䌽一-2)。AX2 は負側に北大，ポプラ通と野幌を配置し，正側に青葉，大谷地之 東札幌を配置した。他の緑地は AX2の0 点周辺に位置した。 AX3 は藻南と真駒内だけを高い正側の位置に配置し, 円山と東 札幌を他の緑地よりも藻南や真駒内に近い位置に配置した。

AX1 と各緑地特性要因や孤立化要因との相関をみると（表一 7), AX1は孤立してからの時間やすべての周辺森林率に対して, 有意水準 $5 \%$ 以下の負相関を示した。このなかで, 周辺森林率と AX1 との相関係数は，周辺地域が拡大するにつれ減少するとい う傾向を明瞭に示した。AX1 と生青形別種数の要因間では, AX1は高木種数と低木種数に対し $r=-0.91$ と $\mathrm{r}=-0.87$ という強 い負相関を示し，木本性つる種数と緑地の総種数にたいしても有 意水準 $1 \%$ 以下の負相関を示した（表一8）。また，草本種数に 対しても有意水準 $5 \%$ 以下の負相関を示した。生育形スペクトル に対しては, AX1は高木種と低木種の割合に対して，住意水準 $5 \%$ 以下の負相関を示した。生有地特性別種数要达をみる（表 $9)$ ，森林種数はAX1に対して最も強い負相関 $(r=-0.92)$ を示 し,ついで州化摔も強い正相関 $(r=0.84)$ を持った。この他沢 筋種数 $(r=-0.75)$ と海岸種数（ $\mathrm{r}=-0.63 ）$ が AX1に対し有意 な相関を示したが, 海岸種は総数 4 種ときわめて少なく, 相関係 数から有為な情報は得られなかった。

総種数と森林種数の間に $\mathrm{r}=0.923$ という高い正の相関がみら れたが，この原因は総種数に対する割合が高いために自動相関が 発生したためである。また沢筋種と森林種はいずれも森林群落の 構成種であることから，これらの 2 種群は森林性植物に含めるこ とができる。

AX2 はどの緑地特性要因や孤立化指標要因に対しても有意な 相関を持たなかったが（表一 7 ），その理由として標本数が少な いこと（相関係数の自由度が 9 以下）の影響が大きかったものと 思われる。AX2 に対して比較的大きな相関係数を持った要因は
緑地面積 $(r=-0.51)$, 形状指数 $(r=-0.50)$ と草地・草原・農地 面積 $(r=-0.49)$ であった。これら 3 つの要因間は $r=0.80$ 以上 の強い相関をもち, 緑地面積が拡がると草地・草原・農地も広が り, 森林斑の形状も複雑になるという結果を示している。

生育形別種数の各要因のうち, 草本性つる種数は AX2 に対し 強い負相関を示し $(r=-0.79)$, 草本種数と総種数も $5 \%$ 水準以 下の有意な負相関を示した (表一 8 )。これら 3 つの要因には $\mathrm{r}=0.8$ 以上の強い相関関係があった。また，AX2 は草本性つる 種の割合に対しても有意水準 $5 \%$ 以下の負相関を示した。生育地 特性別種数の要因に対しては, 耕地・人里種数 $(r=-0.85)$ と帰 化種数 $(r=-0.82)$ だけが AX2 に対して強い相関を示した（表一 9 )。帰化種のほとんどは耕地・人里種なので両者の間の相関は $\mathrm{r}=0.993$ 之極めて強かった。AX2 と相関を持った生育形別種数 の 3 要因群 (総種数, 草本性つる植物種数とその割合, 草本種数) 之生育地特性別種数の 2 要因群（耕地-人里種数, 州化種数) の 間には有意な相関関係がみらなかった。

AX3 は緑地特性, 孤立化指標や生育形別種数のすべての要因 に対して全く有意な相関を持たなかった。しかし生育地特性別種 数の要因のうち, 岩れき地種数とだけ $\mathrm{r}=0.73$ の高い相関を示し た。

\section{4. 考察}

主成分分析法により都市緑地を解析した結果，主要な 2 軸に人

表-7 PCA 軸と緑地特性要因および孤立化指標要因との相関

\begin{tabular}{|c|c|c|c|}
\hline & $\mathrm{AX1}$ & $\mathrm{AX2}$ & $\mathrm{AX3}$ \\
\hline 森林面楼 $(\sqrt{ }$ 変換 $)$ & -0.428 & -0.476 & -0.252 \\
\hline 草地·草原・地面積 $(\sqrt{ }$ 变換 $)$ & -0.151 & -0.494 & -0.103 \\
\hline 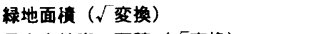 & -0.342 & -0.513 & -0.224 \\
\hline 最大森林斑の面樌（ $\sqrt{ }$ 変換） & -0.404 & -0.452 & -0.098 \\
\hline 最大森林斑の形状指数 & -0.254 & -0.495 & -0.086 \\
\hline 團路長比 & 0.130 & 0.327 & -0.418 \\
\hline 坬立化してからの年数 & $0.693^{\star}$ & -0.033 & 0.152 \\
\hline 周辺100m森林㡭（\%）(arcsin変換） & $-0.864^{\star \star \star}$ & -0.151 & -0.035 \\
\hline 周辺500m森林蛼（\%）(arcsin変換） & $-0.825^{\star \star \star}$ & -0.223 & -0.003 \\
\hline 周辺 $1000 \mathrm{~m}$ 森林率（\%）(arcsin变換） & $-0.807^{\star \star}$ & -0.200 & 0.091 \\
\hline 周辺 $5000 \mathrm{~m}$ 森林锞 (\%) (arcsin変換) & $-0.715^{\star}$ & 0.035 & 0.406 \\
\hline
\end{tabular}

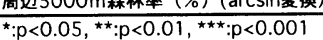

\section{表 -8 PCA 軸と総種数および生育形別種数の相関}

\begin{tabular}{|c|c|c|c|}
\hline & $\mathrm{AX1}$ & $\mathrm{AX2}$ & $\mathrm{AX3}$ \\
\hline 総種数 & $-0.721^{* \star}$ & $-0.641^{\star}$ & -0.044 \\
\hline 草本種数 & $-0.701^{\star}$ & $-0.662^{\star}$ & -0.121 \\
\hline 高木種数 & $-0.913^{\star \star \star}$ & -0.290 & 0.051 \\
\hline 低木種数 & $-0.871^{\star \star \star}$ & -0.215 & 0.276 \\
\hline 草本性つる種数 & -0.442 & $-0.792^{\star \star}$ & 0.081 \\
\hline 木本性つる種数 & $-0.793^{\star \star}$ & -0.388 & 0.204 \\
\hline 緑地単位面積あたりの種数 & 0.116 & 0.200 & -0.437 \\
\hline 草本種の割合（\%）（arcsin変換） & 0.581 & -0.0003 & -0.094 \\
\hline 高木種の割合（\%）（arcsin変換） & $-0.615^{\star}$ & 0.017 & 0.002 \\
\hline 低木種の割合（\%）（arcsin変換） & $-0.637^{\star}$ & 0.058 & 0.158 \\
\hline 草本性つる種の割合（\%）（arcsin変換） & 0.026 & $-0.678^{\star}$ & 0.141 \\
\hline 木本性つる種の割合（\%）（arcsin変換） & -0.383 & 0.244 & 0.077 \\
\hline
\end{tabular}

表-9 PCA 軸之帰化率および生育地特別種数の相関

\begin{tabular}{|c|c|c|c|}
\hline & $\mathrm{AX1}$ & $\mathrm{AX2}$ & $\mathrm{AX3}$ \\
\hline 帰化種数 & 0.386 & $-0.822^{\star \star \star}$ & 0.055 \\
\hline 緑地単位面積あたりの帰化種数 & 0.257 & 0.131 & -0.407 \\
\hline 帰化率（\%）(arcsin変換） & $0.838^{\star \star \star}$ & -0.158 & 0.118 \\
\hline 森林種数 & $-0.921^{\star \star \star}$ & -0.365 & -0.069 \\
\hline 海岸種数 & $-0.627^{\star}$ & -0.253 & 0.354 \\
\hline 岩れき地種数 & -0.517 & -0.114 & $0.732^{\star \star}$ \\
\hline 砂丘·砂浜種数 & -0.345 & -0.532 & -0.435 \\
\hline 湿原種数 & -0.269 & -0.571 & -0.401 \\
\hline 樹幹種数 & -0.466 & -0.579 & -0.297 \\
\hline 沢筋種数 & $-0.754^{\star \star}$ & -0.526 & 0.042 \\
\hline 耕地·人里種数 & 0.333 & $-0.853^{\star \star \star}$ & 0.021 \\
\hline
\end{tabular}

${ }^{\star}: p \leqq 0.05,{ }^{\star \star}: p \leqq 0.01,{ }^{\star \star \star}: p \leqq 0.001$ 
為的作用の影響が反映されていることが判明した。

第一の構造である AX1 は孤立化指標である各幅での緑地周辺 の森林率や孤立化してからの時間と負相関を持ち, 総種数や森林 性植物（森林種, 沢筋種）の高木種, 低木種, 草本種と木本性つ る種の種数とも負相関を持った。一方, 䚻化率に対しては正の相 関を示した。孤立化指標は市街地化の指標でもあるため, AX1 は緑地周辺の都市化の影響がその中の森林群落に現れたことを抽 出しており，都市化により森林が孤立し，森林性植物が減少する ことが判明した。

第二の構造である AX2 は緑地面積, 最大森林斑の形状指数や 草地・草原・農地面積と比較的高い負相関を示した。また AX2 は総種数や生育形別種群中の草本性つる種, 草本種, および生育 地特性別種群中の耕地・人里種と帰化種の種数と有意な負相関を 示した。草本性つる種や帰化種のほとんどは耕地・人里種なので AX2 は緑地に対する人為的な覧乱の影響を反映している; 緑地 の面積が拡大すると耕地・人里種の生育環境である摫乱地が増加 する。耕地・人里種は林緣の林床にも侵入するため, 緑地内の森 林斑の形状指数が高くなることは, 林縁部が増加し, この種群の 増加の一因となる可能性が考えられる。

第三の構造である AX3 は岩れき地種の種数と正の相関を示し, 岩れき地の群落は他の群落と異なる特有の種組成を示すことを抽 出した。なお，この群落は岩れき地という特殊な立地に成立する 群落であり，人為的な影響を受けて成立したものではない。

浜端 $(1980)^{4}$ は武蔵野平地部の二次林で高さ $4 \mathrm{~m}$ 以下の階層 の種組成を主成分分析法で解析した。その結果, 主要な最大の軸 は周辺の宅地率と相関が高いことから都市化による種組成の変化 と見なし，第二の軸は人為的摫乱の強度による変化と見なした。 本研究の結果もこれらの結果之非常によく一致することから，他 の都市緑地でもその植物相が都市化と人為的な筧乱という独立し た 2 要因によって強く影響を受けている可能性が高い。

㷌化率は地域の自然植生の摜乱の指標として用いられてきたが が (沼田・大野 1953) ${ }^{11}$, 本研究の結果, 州化率は都市化の指標 となっており, 人為的な摫乱の指標としては帰化種数がふさわし
いことが明らかになった。この原因は，婦化率に大きな影響を与 える総種数が緑地間の森林性植物の種数の違いに依存しているた めに, 都市化によって総種数が減少し, その結果帰化率の上昇が 強調されるためである。

都市化は緑地内の森林性植物の減少を引き起こす。そこで AX1に対して高い負相関（種スコアがー 0.7 以下）を示した 46 種を抽出した（表一10）。これらの植物のうち 44 種は森林性植物 であり，この中で林床性草本は 30 種 $(68.2 \%)$ を占め, 残りの 14 種（31.8\%）が木本（高木，低木，つる）であった。14 種の 木本のうちチョウセンゴミシ, サワフタギ, 八クウンボク, クサ ギ, ウラジロイチゴ, アズキナシ, サルナシ, コマユミ, ナニワ ズとハリギリの 10 種は鳥散布種子であり, 残りの 4 種は風散布 種子であった。従って, 木本については鳥散布型が最も消失しゃ すかった。なお，AX1に対して正の相関（種スコアが 0.7 以上） を示した種は 5 種あり, それらはすべて耕地・人里種に属する草 本であった。

ヨーロッパで孤立化した自然林之二次林を対象にした研究では, 動物散布型（主に鳥散布型）の種は，孤立化の進行によって散布 者が減るために減少しているという結果が得られている (Dzwonko and Loster, 1988 ${ }^{23}$; Grashof-Bokdam, 1997 ${ }^{33}$; Santos and Tellería, 1994 ${ }^{18)}$ )。本研究は自然林之一部の二次 林を対象にして行われており, 孤立化が鳥散布型木本植物の消失 を引き起こすという結論はヨーロッパでの研究結果とほぼ一致し ている。

一方, 浜端 $(1980)^{42}$ は暖温带の孤立二次林の研究の中で重力 散布種子は孤立化の影響を受けやすいとしているが，そのような 傾向は本研究からは得られていない。また，他の暖温带の孤立二 次林の研究では, 動物散布型 (鳥散布型) の木本の種子が林内に 多数供給されているという多くの研究がある（井手ほか，1994 ${ }^{8)}$; 浜端，1980 ; 服部ほか，1994 $\left.{ }^{6}\right)$ 。しかしながら，鳥散布型の 種が森林の断片化や㧓立化によって増加するという傾向はみられ ていないという研究 (Iida and Nakashizuka， 1995) ${ }^{97}$ もる。 また大久保・加藤（1994） ${ }^{12)}$ は二次林よりも階層構造の発達した

表一10 PCA のAX1に対する種スコアがー0.7 以下の種およびこれらと出現パターンがー致する種の生育形, 生育地特性と出現回数

\begin{tabular}{|c|c|c|c|c|c|c|c|}
\hline 種名 & 生育形 & 生育地特性 & 出現回数 & 種名 & 生育形 & 生育地特性 & 出現回数 \\
\hline エゾ マツ & 高木 & 森林 & 3 & ゼンマイ & 草本 & 森林 & 6 \\
\hline チョウセン゙ミシ & 木本性つる & 森林 & 3 & ミヤマベニシダ & 草本 & 岩れき地 & 6 \\
\hline ギン归方ウウ & 草本 & 森林 & 3 & ナう价多 & 草本 & 森林 & 6 \\
\hline サワフ夕ギ & 低木 & 森林 & 3 & フグンシ & 草本 & 森林 & 6 \\
\hline 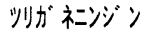 & 草本 & 海岸 & 3 & ウラジ ロ仔ゴ & 低木 & 森林 & 6 \\
\hline 材功スゲ & 草本 & 森林 & 3 & ヤマEミシ & 高木 & 森林 & 6 \\
\hline オオヤマサギソウ & 草本 & 森林 & 3 & ウメガサリウ & 草本 & 森林 & 6 \\
\hline アキカララリリ & 草本 & 森林 & 4 & 任ヤクリウ & 草本 & 森林 & 6 \\
\hline フタリシズカ & 草本 & 森林 & 4 & フデリドウ & 草本 & 森林 & 6 \\
\hline ミヤマニガウリ & 草本性つる & 森林 & 4 & エゾタンポ & 草本 & 森林 & 6 \\
\hline カラフトアカバナ & 草本 & 沢筋 & 4 & 和 & 草本 & 森林 & 6 \\
\hline トチバニンジン & 草本 & 森林 & 4 & 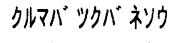 & 草本 & 森林 & 6 \\
\hline クサギ & 高木 & 森林 & 4 & シロパナエルル仿 & 草本 & 森林 & 6 \\
\hline ミヤマ祙 シがヤ & 草本 & 森林 & 4 & フォスイゲ & 草本 & 森林 & 6 \\
\hline ミッバウツギ & 低木 & 森林 & 5 & $7 x^{*} キ+シ$ & 高木 & 森林 & 8 \\
\hline ウシタキリウ & 草本 & 森林 & 5 & 汁/ & 高木 & 森林 & 8 \\
\hline がメハウ & 草本 & 森林 & 5 & オシダ & 草本 & 森林 & 9 \\
\hline ヘクウン゙ク & 高木 & 森林 & 5 & \#ルナシ & 木本性つる & 森林 & 9 \\
\hline こシキュ゙ロ㕵 & 草本 & 森林 & 5 & :בקנ & 低木 & 森林 & 9 \\
\hline 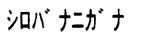 & 草本 & 森林 & 5 & t=7x & 低木 & 森林 & 9 \\
\hline 比斻难 & 草本 & 森林 & 5 & ハキギリ & 高木 & 森林 & 9 \\
\hline \multirow[t]{3}{*}{ トケララン } & 草本 & 森林 & 5 & ヤマニガナ & 草本 & 森林 & 9 \\
\hline & & & & アキノキリシリウ & 草本 & 森林 & 9 \\
\hline & & & & コキザサ & 草本 & 森林 & 9 \\
\hline
\end{tabular}


自然林に近い林の方が鳥による高木種の補充が促進されるとして いる。二次林で鳥散布種の供給が多いかどうかは今後自然林との 比較の上で結論を出さなければならないであろう。

次に, Grashof-Bokdam (1997) ${ }^{3)}$ は周辺 $100 \mathrm{~m}$ 以内の森林率 が孤立化に最も大きな影響を与えるとしているが, 本研究でも, 緑地周辺 $100 \mathrm{~m}$ 以内の森林率が孤立化に対して最も影響が大きい という結果を得た。従って動物散布種子は緑地周辺 $100 \mathrm{~m}$ 以内に ある森林から主に供給されるものと思われる。

都市化による森林性植物種の減少のうち, 孤立化によって説明 される部分は断片化による面積減少や立地環境の多様さの低下に よって説明される部分に比べてわずかである(Ouborg, 1993 ${ }^{14)}$ )。 断片化による森林面積の減少は, 林内草本の種数を減少させる要 因である（服部ほか, 1994 ${ }^{6)}$; Iida and Nakashizuka 1995 ${ }^{9)}$ )。 本研究では緑地全体を対象にしているために, 個々の森林斑に対 する断片化の影響は不明であるが，消失しやすい種の $76 \%$ が林
床性草本であることから，断片化の効果が大きいことが推定され る。

今後, 都市化が緑地の植物相に与える影響について考えていく 上で, 今回の結果は十分といえるものではないが, 市街地の増加 による都市化や人為的な靦乱が緑地の植物相に与える影響につい て一定の考察ができた。今後, 緑地内の個々の群落を対象とした 研究を進展させたい。

\section{謝辞}

本研究の一部は (財) 都市緑化技術開発機構の援助を受けて行 われた。LANDSAT TM データは, EOSAT／宇宙開発事業 団に提供していただいき，GISによる解析手法は（株）パスコ 雨宮有氏之小杉庄一氏にご指導いただいた。また, 帯広畜産大学 紺野康夫氏には本研究全般にわたり，貴重なご助言をいただいた。 ここに記して感謝の意を表する。

\section{引用・参考文献}

1）大都市統計協議会（1997）：大都市比 較統計年表平成 7 年

2) Dzwonko, Z. and Loster, S. (1988): Species richness of small woodlands on the western Carpathian foothill: Vegetatio 6, 15-27

3) Grashof-Bokdam,C.(1997):Forest species as agricultural landscape in the Netherlands: Effects of habitat fragmentation: J. Veg. Sci. 8, 21-28

4 ) 浜端悦治 (1980)：都市化に伴う武蔵 野平地部二次林の草本層種組成の変化： 日本生態学会誌 $30,347-358$

5 ) 原松次 (1992)：札幌の植物：北海道 大学図書刊行会

6 ）服部保・上甫木昭春・小舘誓治・熊懐 恵 美・藤井俊夫・武田義明（1994）: 三田市フラワータウン内孤立林の現 状と保全について：造園雑誌 57(5), 217-222

7 ）日置佳之 (1993)：自然保護区の計画・ 緑地生態学（井手久登・龟山章編）: 朝倉書店, 18-41

8 ) 井手任・原田直國・守山弘（1994）:
孤立二次林における種子供給が下層植 生に与える影響：造園雑誌 57(5)， 199-204

9) Iida, S. and Nakashizuka, T. (1995): Forest Fragmentation and its effect on species diversity in sub-urban coppice forests in Japan: For. Ecol. Manage. 73, 197 210

10）加藤和彦（1995）：生物群集分析のた めの序列化手法の比較研究：環境科 学会誌 8,339-352

11）沼田真・大野景徳（1953）：帰化植物 の生態学的研究 I：植物生態学会報 $2,117-122$

12）大久保悟・加藤和弘（1994）：都市近 郊林の分断された平地二次林における 高木種の補充に関する研究 : 造園雑誌 $57(5), 205-210$

13) Orloci, L. (1973): Ordination by resembrance matricies. Ordination and classification of communities (ed. Whittaker, R. H.): Junk, 249-286

14) Ouborg, N.J. (1993): Isolation, population size and extinction: the classical and metapopulation approaches applied to vascular plants along the Dutch Rhinesystem: Oikos 66, 289-308

15）札幌市（1997）: 街区公園成立要因内 訳 : 札幌市公園計画課

16）札棍市（1997）：札幌圏都市計画市街 化区域および市街化調整区域変更面積 集計：札幌市都市計画課

17）札幌市（1994）：札幌市の地域構造： 平成 6 年地域統計報告書

18) Santos, T. and Tellería, J. L. (1994): Influence of forest fragmentation on seed consumptions and dispersal of Spanish juniper, Juniperus thurifera: Biological Cnservation 70, 129-134

19) ter Braak, C. J. F. (1986): Canonical correspondence analysis: a new eigenvector technique for multivariate direct gradient analysis: Ecology 67, 1167-1179

20) ter Braak, C. J. F. and Prentice, I. C. (1988): A theory of gradient analysis: Advance in Ecological Research 18, 271-317

Summary: We analyzed the flora of 11 open spaces in Sapporo city using Principal Component Analysis. The first axis AX1 negatively correlated with forest-cover ratio in peripheral area and time after isolation, both of which indicated the degree of isolation, and number of forest species. Since isolation of open space was advanced by the increase of urbanized area, AX1 should extract the decrease of forest species due to the urbanization. The second axis AX2 extracted the anthropogenic disturbance affected the flora of open space; The enlargement of disturbed area which positively related with the area of open space increased the ruderal species.

The number of forest plants being extinguished by the urbanization was 30 of grasses and herbs, and 14 of trees. Among the 14 trees, 10 were bird-dispersal and 4 were wind-dispersal. Accordingly, bird-dispesal species would be extinguished by the isolation of woodlot, and forest-cover ratio within $100 \mathrm{~m}$ of peripheral area was most effective for the isolation. However, because all grasses and herbs was forest-floor species, the effect of fragmentation causing the decrease of woodlot size would significantly affect. 